I Universidade Estadual de Campinas (Unicamp), Instituto de Filosofia e

Ciências Humanas, Campinas, SP, Brasil

bernardofmachado@gmail.com

https://orcid.org/o0oo-000I-8884-2357

Bernardo Fonseca Machado'

\title{
SOCIAL EXPERIENCE AND US MUSICAL THEATRE ON SÃO PAULO'S STAGES ${ }^{1}$
}

Since the turn of the millennium, shows originating on Broadway, New York, have begun to be produced in many different cities around the world. During the I980s and I990s, American entrepreneurs developed strategies for selling theatrical works in cities of various nations (Machado, 20I8). These producers elaborated a procedure for selling the rights to Broadway shows to other countries: they started to offer the rights to musicals for purchase by foreign companies via a rights licensing agency, Music Theatre International (MTI) (Gamerman, 2010).

Brazil was one of the countries that invested in these productions. Particularly in the São Paulo theatre scene at the start of the new century, a series of indicators demonstrates the vigour of this enterprise: the number of shows, the size of audiences, the financial sums generated, and the construction of new buildings. For example, there were three versions of Broadway shows between I950 and I969, four between I970 and I979, rising to seven between I980 and I989, and the same number between I990 and I999. In the decade from 2000 to 2009 , the conditions for producing musicals changed and the shows rose to 20 and, finally, between 2010 and 2016, jumped to 48 (Cardoso, Fernandes \& Cardoso Filho, 2016).

The data from the last few years reveals how the public embraced these musicals with particular enthusiasm. In 200I, Les misérables attracted 350,000 theatregoers over the I I months it was running. More recently, between 2013 
and 20I4, The lion king sold 800,000 tickets over its almost 20-month run (Cardoso, Fernandes \& Cardoso Filho, 20I6; Brasil, 20I4). The volume of money needed to produce each show is also remarkable. Time 4 Fun, one of the main companies specializing in the area, made use of the tax breaks provided by the Rouanet Law to stage I5 musicals between 200 I and 20I6. The cheapest, Sweet Charity (2006), spent R\$I,446,245 (equivalent to US\$ 683,642.I 6 at the time) and the most expensive, The lion king (20I3-20I4), received funds of R $\$ 28$, I I 2,570 (equivalent to US\$ I I,933,343.24 at the time). ${ }^{2}$ As a parameter for these budgets, the Theatre Promotion Law of São Paulo municipality ( "Lei de Fomento ao Teatro" created in 2002 to finance theatre in the city) allocated $R \$ 15,894,042$ in funding (or US\$ 6,8I0,370.2I) in 2013 to be distributed among 30 theatre projects.

Furthermore, in the space of a little over I5 years, between $200 \mathrm{I}$ and 2016, seven new theatres were built to stage these productions. The smallest - the Teatro Net São Paulo, opened in 2014 with 508 paying seats. The largest the former Teatro Abril, now the Teatro Renault -, reformed in 200 I specially to put on large musicals, can accommodate up to I500 spectators. By way of comparison, less than $5 \%$ of theatre spaces in São Paulo, as of 2004, were able to receive more than I0oo people and less than I5\% possessed more than 500 seats (Machado, 2012; Almeida Júnior, 2007).

While the twenty-first century is impressive for its entrepreneurial energy, Brazilian producers and artists were already dedicating themselves to the genre in the I960s, I970s and I980s. At the time, musicals were sporadic, however, and there was no regular training of groups of artists specifically for this kind of theatrical production. The process involved in staging a show varied greatly: the type of financing depended on the abilities of the producer responsible and Brazilian actors lacked the technical skills in singing and dancing to perform the musical numbers adequately. In the I 980 , there was a small shift: pedagogical institutions began to teach repertoires from these musicals to teenagers and adults. But it was only in the final years of the Ig9os that the environment changed. The condition for national theatre productions was altered with the advent of a new Cultural Incentive Law (the controversial Rouanet Law). In 200I, São Paulo witnessed the convergence of these previously diffuse factors. A Broadway production called Les misérables inaugurated the reform of the Teatro Abril in the city centre. The aspirations of artists and producers, while scattered in small projects before, now seemed to encounter a strongly directed formula for work. In the years that followed, the show came to be considered a landmark for the recent history of musicals in Brazil. After then, the scene developed rapidly. The number of productions swelled and there was a specialization of professionals from the area.

My intention is not to sketch a complete panorama of the shows produced in this period. For this, I suggest the book by the actor Gerson Steves (20I5) - which lists the main musicals produced in the country - and the article 
by Cardoso, Fernandes, and Cardoso-Filho (20I6) - which provides for a brief historical overview based primarily on quantitative data. It is worth emphasizing that the history of musical theatre production in Brazil is not limited to US examples, much the opposite. From the nineteenth century to the mid-twentieth, for example, the spotlights witnessed the vitality of review theatre (Veneziano, I99I; Lopes, I999; Gomes, 2004) and many musical shows played a key role in artistic and political resistance during the period of military dictatorship (Marques, 2014).

This text scrutinizes a selection of these musical theatre productions: it takes as its subject the Brazilian versions of US originals and investigates the essential lines of tension that explain the abundant recent production of these shows in the São Paulo capital. As well as dialoguing with the literature on the topic, I have also turned to primary sources. Using online document research tools, I consulted news items and reports published in the Folha de S. Paulo and O Estado de São Paulo newspapers between I 980 and 2015. Also instrumental were the lengthy conversations recorded by the journalist Tania Carvalho $(2008,2009)$ with artists working in the area. In addition, I interviewed 37 professionals from the sector - actors, directors, producers, and journalists - paying close attention to the histories and memories that they recounted. I was present at events organized to discuss or celebrate the musical theatrical productions and I enrolled as a student on a theory workshop on the history of the topic. Finally, I turned to the Federal Government's official data on the amounts spent in the sector under the provisions of the Rouanet Law. Having obtained the documents and materials, I selected some aspects, checked facts, and sought to contrast opinions and trajectories.

This work seeks to offer a contribution to studies in anthropology and sociology that have been investigating the relations between theatrical practices and social experiences (Arruda, 200I; Pontes, 20Io; Sarlo, 20Io; Charle, 20I2; Krüger, 2008; Machado, 20I2, 20I8; Romeo, 20I6). I am interested in describing how particular agents orchestrate multiple procedures and ambitions in organizing this unique setting. I seek to identify how these subjects mutually position themselves in this diverse theatrical environment. I characterize the desires and choices, and develop a line of argument that aims to render intelligible the multiple events that unfolded.

\section{SPORADIC PRODUCTIONS, DESIRES IN SYNTONY}

During the economic and political hangover endured by Brazil in the I960s, some Broadway musical productions made a small appearance on São Paulo's stages. At the time, they depended on the enterprise of ambitious independent producers like Victor Berbara. ${ }^{3}$

Born in 1928 to a Lebanese father and a Portuguese mother, Berbara trained as a psychologist at Columbia University and began his career in the 
I940s as a producer of communication programs. He worked in large advertising agencies, on National radio, and for TV Globo in its early years. Highly active and restless, in I959 the young man decided to try his luck as a theatre director. Little did he know that the first Broadway musical in Brazil would be staged by him. At the time, an American producer had decided to expand presentations of My fair lady 4 to Mexico, Argentina, and Brazil. Berbara received the invitation and, months later, embarked for the capital of Mexico. There the "gringo" team would teach them the procedures needed to put on the show.

As the person responsible for funding the musical in Rio, Victor did not want to fund the investment entirely with his own money. The producer therefore sought partners willing to invest capital and cover the initial costs: in exchange, they would receive a portion of the profits - each would own $25 \%$ of the show. "I never regretted it," he declared, "My fair lady was a money-making machine!" (Carvalho, 2008: I30). The enthusiasm at the premiere was evident in the report by O Estado de São Paulo, 25 July I963. My fair lady was announced as "the first contact of São Paulo's audiences with a musical comedy, as it is understood in the United States." Discussing the topic in retrospect, Berbara would declare years later: "Never had that type of show been staged in Brazil before then. There was the opera experience: static scenes in three or four acts. In My fair lady, the scenery changed, even moving about during the scene" (Carvalho, 2008: I37).

In the following years, other musicals of Anglo-Saxon origin would hit the stages and fill the stalls: Hello Dolly (I966), Hair (I969); Fiddler on the roof (I97 I); Man of La Mancha (I972); Jesus Christ Superstar (I972); Godspell (I974); Pippin (I974); Rocky horror show (I975), and Evita (I983). Despite the diversity of their plots, the varied forms of staging, and the settings depicted, the shows had some elements in common: the Broadway origin and the aura of foreign glamour.

Even so, the experiences were intermittent and depended on the individual desire and autonomy of producers like Berbara. They were far from a world of systematic regularity and specialized professionals. Furthermore, the cast brought its own issues. The producer of My fair lady himself hesitated over casting the actress for the main role. One of the candidates was Tônia Carrero, who, at the height of her beauty and fame, "lacked the humility to accept that she could not sing. She thought that with a few lessons she would get there, but she wouldn't, I'm sure" (Carvalho, 2008: I3 I). ${ }^{5}$ The other candidate was Bibi Ferreira. Concerning her, Berbara explained: "I didn't think she was right for the part; it was complicated. The person had to be a singer and Bibi isn't; the actress must have a lot of charisma, which Bibi doesn't. She was always about technique" (Carvalho, 2008: I3I). The role had been obtained due to the lobbying of Bibi's mother, who insisted on her daughter being hired.

In the I980s, a new set of agents joined the scene. Walter Clark, also coming from the TV networks, debuted as a theatre producer on the stages of 
Sérgio Cardoso with the show Chorus line. ${ }^{6}$ Born in 1936 , he became the artistic director of Globo in 1965 at the indication of Berbara himself, his friend. Clark would remain in the post until 1977 when he fell out with the patriarch of the Marinho family, Globo's owners. His experiments with theatre began after this television phase.

To pay for the costly undertaking, budgeted at 300 million cruzeiros, ${ }^{7}$ he dreamt up a share system: he made 44 shares available for purchase by anyone interested. Each person would obtain a return, corresponding to the portion of shares purchased, from the revenue generated at the ticket office. ${ }^{8}$ Chorus line became a success and was decisive for the career of one actress in particular: Claudia Raia. A native of Campinas, in 1966 her artistic career would take off. Ever since a girl she had dedicated herself to becoming a performing artist. Her mother, owner of a ballet school, ensured she enrolled for classical ballet. At the age of I3, she went to live in New York alone and studied at dance schools for a year and a half.

Raia joined the cast of the show produced by Walter Clark when she was I6. Figures from Globo invited by the producer were enchanted by the young woman and asked her to work at the broadcaster. In the following years, she exploded onto the scene as an actress playing the prostitute Ninon in the soap opera Roque santeiro (1985) and would star in her first pocket show - Essas noites assim (1987) - in a nightclub in Ipanema. At the time, Raia lamented the absence in Brazil of "a school of art where any artist can learn everything they want and discover themselves" (Cavalcanti, I987).

In fact, such complaints about the absence of technical teaching were far from unique. In I989, the director Jorge Takla also expressed his dissatisfaction. Born in I95I, and trained at the School of Fine Arts and the National Conservatory of Dramatic Art, in Paris, he was explicit about how, at the end of the I980s, Brazilian actors were unprepared: "No actor is ready to handle a musical like this" (Pimenta, I989: DI). He was referring to Cabaret (I989), a show set during the period of the Nazi rise to power in Germany. To solve the problem, before official rehearsals began, the director scheduled a "pre-rehearsal" phase just for improving bodily techniques. The O Estado de São Paulo report of 20 May I989 describes a cast uncertain about singing and dancing skills: "For now, the master of ceremonies, Sally Bowles and company still get their steps wrong, look down at the ground when they should look to the sky, and almost break the boards with the weight of their bodies" (Pimenta, I989: DI). The observation reveals the lingering perception of a dearth of technique, first signalled by Berbara years earlier. Much of the national cast lacked the basic skills for singing and dancing - at least by US aesthetic standards. ${ }^{9}$

Since that time, shows premiered that were either directly linked to Broadway or inspired by US musicals. At the end of the I 980 s and the beginning of the I990s, a series of shows were staged whose design, according to a report 
in the Folha de S. Paulo, was "the most North American possible." "The intention," the journalist alleged, "was to do something along Broadway lines" (Camargo, I989: E-3). For instance, Claudia Raia's surname - meaning "line" or "limit" - had become the epicentre of numerous puns: Não fuja da raia ("Stay on the line," I99I), Nas raias da loucura ("On the limits of madness," I993) and Caia na raia ("Fall in line," I996). The shows were stripped down to a simple plot, composed of musical, choreographic and comic sketches, monopolized by Raia herself (Oliveira, I996).

The actress was not alone. A generation born in the I960s and I970s dialogued with references to foreign music. There were, for instance, producers who ventured to make musicals that freely alluded to Broadway. In Rio de Janeiro, the young Charles Möeller and Claudio Botelho experimented with new formats. The former was born in Santos (SP), in I967, and had pursued a career as an actor from an early age. Botelho, meanwhile, born in I964, a native of Araguari (MG). He had trained as an actor but, finding work difficult to come by, decided to pursue a new profession as a translator and composer. The young men first met at the start of 1990 and began a long and enduring conversation about musicals. Their first works merged songs from a variety of shows and by different composers. Such was the case of Hello Gershwin (I99I) and As malvadas (Bad Girls, 1997) (Carvalho, 2009).

Another fan of musicals, Miguel Falabella was at the time associated with his involvement in the so-called teatro besteirol (nonsense theatre) of the I 980 , his participations in Globo TV soaps, and his work as a playwright (Castelo, I995; Gama, I998; Wasilewski, 2008). Born in São Cristóvão, in Rio de Janeiro's North Zone, in I956, he had a short experience with a musical show in I994. In Falabella canta Disney ("Falabella sings Disney"), the author inaugurated the Café do Teatro in the Gávea Shopping Mall in Rio de Janeiro. The show's director said on the occasion: "It was two exhausting months of rehearsals since nobody there was used to singing" (Dias, I994).

A set of people who shared foreign aspirations thus started to become involved, little by little, in the performance of musical works either directly informed by shows produced for Times Square or filled with allusions to Broadway. These figures - who cultivated the theatrical terrain and learned about Broadway's artistic conventions - were fundamental to enabling shows originally from New York to be systematically staged in São Paulo from the 2000 s onward. But before proceeding further, other important elements of this scene need to be described.

\section{PEDAGOGICAL PATHS}

The I980s also witnessed the beginning of an unprecedented pedagogical environment. As well as teaching vocabulary and grammar, the English language school Cultura Inglesa started to offer classes in Musical Theatre to adult stu- 
dents. Founded in 1935 by the British consulate, in 1979 the institution decided to experiment with staging a musical show in English with students from the choir. The experiment proved something of a success. Since then, more than 40 works have been performed.

The initial idea behind the school's project had not been to provide professional training to aspiring actors. Nevertheless, during the I99os the establishment became "a hothouse for people who wanted to make musicals but had nowhere to go. Because there were no courses, there was no scene," as former student Daniel Salve pointed out. A native of São Paulo, Salve was born in 1976 and debuted on stage at the age of 15 in professional shows for children. When he first learnt about the institution's course for musicals he thought little of the idea: "Just imagine, I'm a professional. Audition for an amateur production? I turned up and was enchanted. I went, took the audition, and passed! Cultura Inglesa was a school," he declared.

Enrolled students, the sons and daughters of liberal professionals and public workers, generally came from the same social background: most of them studied at private schools in São Paulo city and shared a taste for pop music. In the environment provided by the foreign language course, these similar interests converged and, over the next few years, fertilized the city's stages with musicals referring to Broadway. Here the friendship between Daniel Salve and Rodrigo Pitta provides a perfect example. The young men first met in I 992 and, in the years that followed, worked together on seven shows put on by Cultura Inglesa. In I997, they decided to travel together to New York: Pitta spent eight months studying Musical Theatre Direction at the American Music and Drama Academy (AMDA), ${ }^{\text {10 }}$ while Daniel, between singing and dancing classes, found time to audition for the musical Rent. ${ }^{\text {II }}$

After more than a year, the friends returned to Brazil in 1998 and decided to premiere the show Pocket Broadway in the Studium theatre in Rui Barbosa Street, São Paulo. Open from Friday to Sunday, the show was described as "a mix of various musicals performed on Broadway, including The phantom of the Opera, Les misérables, Grease, Hair and The lion king" (Pocket Broadway, I998: D2). The production was a success according to the new artists. The musical closed after running for almost a year and achieved a total audience of around 20,000 (Rocha, 2000).

The following year, I999, Salve obtained the desired role in the Brazilian version of Rent - to be described later. The investment in time and money, as well as the experience at Cultura Inglesa and his studies in New York, led to him being selected from around 900 candidates. On the occasion, the producer responsible explained in a report published in O Estado de São Paulo: "This is definitely not a show for amateurs [...] It's impossible for actors who don't know how to sing, you can't bluff it" (Gama, I999b). Unlike the technical difficulties faced by casts in previous decades, younger Brazilian artists managed to find 
spaces to learn these skills.

In the mainstream media, the publications contributed to circulate the discourse favourable to Broadway shows. On 20 March 200I, Pitta began work as a special correspondent for Estadão, reporting as a specialist in US musicals. Excited, he wrote: "It is incredible how in such a short time it has been possible to create a real panorama of growth in the fledgling industry of musical productions in Brazil." His diagnosis revealed "an activity that, in São Paulo, began in a small group of theatre studies at Cultura Inglesa [...] and today has transformed into a small industry within the cultural scene of the Rio-São Paulo axis" (Pitta, 200I: D7). The inflated relevance of the school echoed in the young man's own trajectory. Ultimately, in his view, former students like himself were now guiding the city's theatre scene.

Indeed, another pedagogical venture also emerged from the Cultura Inglesa school, coordinated this time by the choreographer Maiza Tempesta. With wide experience as a dancer, she had participated in the I980s in the musical Chorus line in both Brazil and New York. In I997, the institution hired the new teacher to help stage musicals for adult students. Tempesta, however, was troubled by the absence of courses for young people: "this age group of teenagers had nowhere to take courses or even any shows to watch, they were stuck in a vacuum." The proposal to give musical theatre classes to adolescents emerged in I999: The Teen Broadway West End - a name simultaneously referencing the United States and London. At the hands of Brazilian professionals, the spaces available for people to experience foreign musicals gradually expanded.

A new generation of young people familiar with the New York references was slowly formed. Alongside other initiatives, the pedagogical ventures proved that, in financial and cultural terms, a change had taken place in the city of São Paulo. However, the production of major shows vied for a place under the sun with another aesthetic genre also emerging at the time.

\section{DISPUTES OVER THE LAW}

The I990s ended with a different configuration emergent in the theatre world, both from the viewpoint of the agenda of aesthetic conventions, and in terms of the cultural policies being implemented.

On one hand, a portion of the artistic field defended the so-called "research theatre," According to this convention, when staging a show, it was essential to reflect a deep respect for its content (Costa, 2009; Fernandes, 20Io; Machado, 20I 2). Artists recently graduated from public universities in the midI 990 s guided a section of the city's theatrical production. Many groups originated from this period, including Cia. de Teatro Os Satyros (I989), Parlapatões, Patifes e Paspalhões (I99I), Teatro da Vertigem (I992), Cia. do Latão (I996), and Cia. da Revista (I997) (Machado, 20I2). The search for financial and professional stability motivated, in large part, these actors, striving to achieve artis- 
tically and critically successful productions.

Cultural policies, meanwhile, evolved in tandem with decisions taken in the federal sphere. Law 8.3I3/9I, known as the Rouanet Law, had become routine during this period (Gonçalves Dias, 20I4). Among its mechanisms was sponsorship: individuals or entities could support cultural projects whose financial amounts and range had to be approved by the Ministry of Culture (MinC). Each proposal was submitted to the ministry, detailing the budgets, and indicating how the funds obtained through the tax exemptions would be used. Consequently, the law defined a new relationship between cultural producers, the public administration, and sponsoring companies. In the first years, between I 992 and I994, the amount of funds spent was less than $6 \%$ of the total of R\$ 250 million (or US\$ 295 million at the time) made available by the State in the form of fiscal incentives (Weffort \& Souza, I 998). It was only after I995, following a wide-ranging reform, ${ }^{\mathrm{I} 2}$ that use of the law become more routine.

This exponential increase coincided with the running of the Ministry of Culture during the first and second mandates of President Fernando Henrique Cardoso (I 995 to 2002). From I 995, by determination of Cardoso himself, the law was projected as the principal mechanism for funding culture in Brazil. It would solve the problems diagnosed by the minister, Francisco Weffort: "It must be recognized [...] that we are an ample consumer market for culture and that the culture we need and cannot produce will have to be imported" (Weffort \& Souza, I998: 25). The declaration encapsulates the practices that guided cultural policies from I 995 and would continue to inform the minister's initiatives until the end of his mandate in 2002.

According to the sociologist Maria Arminda Arruda (2003) in a critical survey of the policies at the end of the "FHC era," MinC's decisions were based on the premise that the State would only act as a regulator of practices, leaving the free market to promote economic and cultural development. The tax incentive laws, especially the Rouanet Law, would allow companies to invest in culture according to their brand interests. The result, Arruda (2003: I8I) concludes, was "a kind of migration of procedures typical of the culture industry and the advertising market" inside the public sector.

The term "cultural marketing" began to be applied to any action that used "culture" as a means of communication to publicize the name, product, or image of a sponsoring company. Following the widespread uptake in the use of the Rouanet Law, the process of company sponsorship and investment transformed this marketing model into a habitual tool in Brazil (Sá Moreira, 20I4; Gonçalves Dias, 20I4). Companies invested in "cultural products" capable of adding value to their image, selected projects strategically in line with brand marketing, and created departments responsible for evaluating the sponsorship.

In I998, Márcio Souza, ${ }^{\mathrm{I} 3}$ president of Funarte, had foretold: "Although group theatre is once again visible, it cannot be forgotten that theatre is also a 
commercial activity that needs to reconcile its productions with the logic of the market" (Weffort \& Souza, I998: 207). Even this theatre, he continued, "is a risky investment," which is why a law like Rouanet was urgently needed. The big change took place in I999 with a Provisional Measure that altered Article I 8 of the Rouanet Law and increased the possibility of a Ioo\% reduction of income tax in the case of theatrical arts projects. As a result, the volume of funds raised exploded. Between I 999 and 2000, for example, the increase was $88 \%$, jumping from $R \$ 25,655,375$ to $R \$ 48,389,275$ (or US $\$$ I $4,340,623$. I 5 to US\$ 24,746,484.09).

The rapid increase in funding was not met with immediate celebration, however. Some theatre groups reacted. In May I999, they published a manifesto against the decisions of the Ministry of Culture, opposing in particular the reform of the law. Calling itself the Movimento Arte contra a Barbárie (Art Movement Against Barbarism), the group denounced official government policy and accused it of limiting culture to the commerce of entertainment (Costa \& Carvalho, 2008; Machado, 20I2; Romeo, 2I6). The director Hugo Possolo, a founder of the Parlapatões group, declared in an interview given to the newspaper O Estado de São Paulo: "No investment exists to continue the development of artistic works. On the contrary, what prevails is a policy of events, which treats theatre and other areas as happening, valued not for their artistic content but for their publicity potential" (Weiss, I 999: D3). Although the collective of united artists was "politically heterogenic" and did not advocate any one aesthetic project, it brought them together "to fight the common enemy: commercial theatre and the 'marketing events'" (Romeo, 2016: 62).

It was into this arena of disputes that the musical Les misérables disembarked in the country. We are in $200 \mathrm{I}$ and the producer Corporación Interamericana de Entretenimiento (CIE, whose history I describe in the next section) raised $R$ \$ I,33I,54I (or US\$573,84I.I5 at the time) through tax exemptions under the Rouanet Law for staging the show in Portuguese. A new phase of using the law came into force, offering the economic conditions for large US musicals to arrive in São Paulo. For some of the creators of São Paulo theatre, Musical Theatre merited a new label: a synonym of commercial theatre, and a synthesis of "barbarism." This explains why a section of the performing arts departments of the public universities of the State of São Paulo have not developed - at least in recent years - studies of the topic. Many of the generation of professors employed at the university, and those replacing them, belonged (or were sympathetic) to the Movimento Arte contra a Barbárie. Academic production took a political side: the polarization of "research theatre" versus "commercial theatre," although already in existence earlier (Ridenti, 20 Io; Marques, 20I4), acquired fresh impetus during this period.

Added to this was the defence of an aesthetic that, in many aspects, distanced itself from the practices of Musical Theatre. Professor Silvia Fernandes 
(2010: I 22), from the USP Department of Theatre, argues that "theatre" over recent decades in São Paulo (and elsewhere) has been "motivated by the desire to test its limits, stretching the traditional sources of its production to breaking point". This was a research aesthetic that aimed to avoid the logic of "representation" - that is, it eschewed illusions and fictional plots in favour of theatrical actions comprehended as "more real." This aesthetic agenda, however, did not match the concerns of the professionals involved in a large portion of the musicals (McMillin, 2006).

A system of theatrical classification was at work, therefore, based on people's taste, located on an interface with the market, and immediately referring to a specific political stance (Bourdieu, 2007). The effect led to a polarization through which musicals were defined as direct agents of foreign capital in the country, complicit with the national "culture industry" itself. The heated escalation with its unpredictable results cooled after the publication in 2002 of the Lei de Fomento ao Teatro (I3.279/02) by the São Paulo City Council (Machado, 2012; Romeo, 20I6). Designed to support the creation and continuation of theatrical research and production projects, the new law met the demands of the different groups, reinforcing the tension already existing between them. After 2002, each theatre sector began to be supported by a separate state mechanism.

To develop the argument, it is necessary to keep in mind how the Rouanet Law removed the risks to producers interested in musicals. As money previously allocated to the Federal Revenue, using it for culture generated - in the eyes of banks and companies - the potential to expand the divulgation of their brands and using lost funds (otherwise "consumed" by tax payments) in a profitable way. In other words, symbolically significant cultural events were associated with the company in the agendas of Brazilian metropolises. Theatre producers, for their part, saw the law as the possibility to stage expensive musicals, capable of drawing in the public and generating profit. The future seemed promising.

\section{CONVERGENCES}

The dispersed initiatives of the previous decades assumed a more definite course from 200I. Manipulated by some central figures, the desires, sporadic in the past, now converged. I turn the spotlight to three specific names: Giuliano Caterini, Fernando Altério, and the company Corporación Interamericana de Entretenimiento. Their interests, initially independent, produced a sequence of theatrical events that eventually synthesized previously diverse economic, aesthetic, and emotional expectations.

Born in the city La Spezia, in Italy, in 1944, and raised in Argentina, Giuliano Caterini arrived in Brazil in 1964, the year of the military coup. He married, had two daughters, and never left the country again. Unknown then in the São Paulo theatrical world, he adopted a stage name very early on: Billy 
Bond. His career began in 1978 as the singer in a punk band. In the next few years, he worked as a producer of records and video clips. At the end of the I 980 s, Bond decided to set up a theatrical production company - Black and Red - and dedicate himself exclusively to direction and to running two theatres: Jardel Filho and Teatro Brigadeiro, both on Brigadeiro Luís Antônio Avenue in São Paulo.

During the same period, in the Moema neighbourhood, the entrepreneur Fernando Altério had invested in building a new theatre: The Palace. Born in I953, a producer of national and international shows, Altério became a regular figure in the social columns over the I990s - he held parties and dinners, announced contracts with artists, and made news winning a cookery competition. His business decisions became the most daring at the end of the rg9os, when construction work began on a theatre on the banks of the Pinheiros river: Credicard Hall. An unknown Mexican company appeared as a partner of the project and promised to change the cultural circuit of the city.

The Corporación Interamericana de Entretenimiento was formed in I990 in Mexico City. At the outset, it promoted live events solely in the national capital. By its second year, however, the signing of an agreement with Ticketmaster Corporation - a US ticket sales company - expanded its show business operations to the whole of Mexico and Latin America. In I996, the corporation signed a licensing contract with another conglomerate: Walt Disney Theatrical Worldwide Inc. Thereafter, CIE was authorized to stage shows from the Disney portfolio in Latin America, Spain, and Portugal. The first production would be La bella y la bestia ("Beauty and the beast"), which premiered in Mexico City in I997.

In January I999, the Mexican company decided to expand its operations to Brazil. As a strategy, it acquired $30 \%$ of Stage Empreendimentos - a consortium owned by the aforementioned Fernando Altério with some other partners. In parallel, CIE also signed a partnership with Billy Bond's company to ensure an arm in show production. In the negotiation, the Mexicans acquired two theatres previously owned by the Italian: Teatro Ópera and Teatro Jardel Filho. The objective was to produce two musicals in São Paulo, Rent (I999) and O beijo da mulher aranha (2000). The shows would serve as an experiment to test the economic viability of Broadway productions in the country.

In November 1999, Rent premiered at Teatro Ópera with a budget of US\$ 400,000 (corresponding to $\mathrm{R} \$ 776,920$ at the time and $\mathrm{R} \$ 2,699,432$ today). ${ }^{\mathrm{I}}$ For the casting, a panel including a US director and choreographer arrived in the city. The selection process was not as problematic as Billy Bond had imagined: "there's a new generation that sings, acts and dances well enough to give you goose bumps" (Gama, I999a: DI7). Daniel Salve, the actor selected for the lead role, had his CV boosted by the shows at Cultura Inglesa and his studies abroad. The São Paulo actress Alessandra Maestrini, born in 1977, had worked on the 
show As malvadas, the first musical production by Möeller and Botelho. Salve and Maestrini proved how, unlike the shows of earlier years, actors in Brazil were now able to perform the songs, choreography and acting on stage according to US parameters.

The production of O beijo da mulher aranha ("Kiss of the Spider Woman", 2000), ${ }^{15}$ for its part, was budgeted at US $\$$ I million (corresponding to R $\$$ I $, 842,900$ at the time, worth $\mathrm{R} \$ 6,403,2 \mathrm{I} 2$ today). ${ }^{\mathrm{I}} \mathrm{A}$ ton of machinery and hundreds of computerized scenery and lighting changes were brought to the production's design. To meet these demands, the Teatro Jardel Filho was reformed. The leading actors were Claudia Raia and Miguel Falabella. According to a report in Estadão (Nunes, 2000a; 2000b), the show was the realization of one of Raia's oldest dreams: "The Spider Woman is a fetish, a strong character, which matches my personality," she told the newspaper. In an anecdotal tone, she added: "The funniest thing is that the first time I watched the show, on Broadway, I met Miguel [Falabella] and we both said how we wanted to put it on stage one day" (Nunes, 200ob). Another fan of musicals would join the group of artists involved. During the first rehearsals, singers had difficulties with the version submitted by the first translator. Raia sought an alternative solution and recommended the already well-known Claudio Botelho. He took the test, passed, and was hired.

At the time, the Mexican company's work model was an innovation. As the productions were large and expensive, the foreign owners of the rights demanded an organized system already put into practice in the original productions. It became common for theatrical work to be divided into sectors: Production (with the production director, production manager, executive producer, administration, accountancy, ticket sales), Marketing, Press, Artistic Team (artistic director, resident director, musical director, choreographer), the Cast (main actors, understudies, chorus, swings), and Technical Team (technical director, costume designer, accessories designer, automation, machinery, sound engineer, wig stylist, makeup artist, special effects technician, sound designer and lighting designer). The form in which the backstage of shows was organized derived - with varying degrees of approximation - from these guidelines (Pierce, 2013; Duarte, 2015).

For many artists, Rent and O beijo da mulher aranha offered a job, as well as the introduction of new working conditions thanks to the economic vigour promised by CIE. In March 200I, the supplement Economia in the O Estado de São Paulo newspaper observed the hegemony that the company had achieved in Brazil: "The Mexican group Corporación Interamericana de Entretenimento (CIE) is on the way to becoming the largest company in the country's show business industry" (Medeiros, 200I: B30). The report claimed that US\$ 45 million ${ }^{\text {17 }}$ had been invested in just two years - it had bought Stage Empreendimentos, taking control of theatres like Credicard Hall and DirecTV Music. Altério became the president of the company in Brazil and Billy Bond was chosen as the person 
responsible for the theatre sector. In March 200I, Alterio explained: “I don't even call CIE a Mexican company anymore, but a company of a globalized economy" (Medeiros, 200I: B30). After all, according to him, 70\% of the group's shares were investment funds, divided among American (80\%) and European (20\%) financers.

Among his various plans, the president revealed the idea of "installing a mini-Broadway" in the Bela Vista region (Medeiros, 200I: B30). The production of shows like Rent (I999) and O beijo da mulher aranha (2000) paved the way. The musicals were presented in the theatres acquired by CIE with an organizational structure compatible with the "model" exemplified by US professionals. At the time, Altério stated: "CIE has been growing at a rate of 35\% to $40 \%$ per year in the world and Brazil is the number one priority now" (Vale, 200I: E5).

"Miserable millionaires" was the title given to the report announcing the show Les misérables to readers of the newspaper Folha de S. Paulo, on 24 April 200 I - a day before the musical's official opening. Although the headline had a critical tone, the content of the text was fairly informative. It highlighted the sums involved in the enterprise: 38 versions toured worldwide over a 16 -year period, while US\$3.5 million had been spent on the Brazilian production, equivalent to $R \$ 7,885,500$ million at the time ( $R$ 24,023,295 in December 2020).

In the pages of the country's largest circulating newspaper, the project's international ambitions were clearly apparent: "To claim its place once and for all in the globalized circuit of musicals, Brazil sees the inauguration of a space in SP, the Teatro Abril, previously called the Paramount" (Santos, 200I). Closed since I996, the building was frequented by São Paulo's high society in the I940s and I950s. In the I960s, it served as a setting for the large festivals of MPB (Brazilian Popular Music). According to the report, the reform aimed to "recover lost time" and reverse "the decline" after the building had been divided into five spaces showing a mixture of porn films and children's plays. Purchased by CIE, the restoration work cost around R\$ IO million (US\$ 4,309,60I at the time). The place was completely transformed and equipped to meet the technical requirements of large scales - an orchestra pit, sound desks, modern lighting and a huge audience. The report focused on the internationalization that the production would represent, marking a definitive event for the city - a before and after. The funds evoked by the article left no room for doubt: the country would be joining an already consolidated entertainment network and, once inside the "club," it "would never again leave."

On 20 April 200I, Guia da Folha reporting on the series of events, stamped the headline: "Broadway is here." For Staut (200I: Io), "The inauguration of Teatro Abril signified another step in the consolidation of a kind of São Paulo mini-Broadway in the case of the Mexican company Corporación Interamericana de Entretenimiento". Some paragraphs later, it was the turn of Altério to declare: "We decided to invest in the [Paramount] theatre due to its cultural and architectural importance. The Bela Vista region has a similar history to that 
of Broadway [...]" As the producer said: "In the I920s, when the Paramount was constructed, the region was undergoing a period of cultural effervescence. The Paramount also hosted the first staging of a musical in Brazil, My fair lady, in I966" (Staut, 200I: I0). The rhetoric played between reiterating the national imaginary and mobilizing foreign references. The musical My fair lady appeared both as an anchor of the past - capable of helping justify the reform - and a lever to confer prestige to the expensive venture. CIE's choice of the building thus aimed to produce both tradition and a prospect for the future.

The successful consolidation of an articulated system of musicals would be celebrated repeatedly over the following years. Les misérables became something of a symbol: it was a metonym for the vectors that converged in São Paulo. CIE's experiences would subsequently become exemplary and would shape new enterprises. The company catalysed actors, translators, directors, and investors through its undertakings.

\section{CONCLUSION}

In the following years, the capital interests - American, Mexican, and Brazilian - were able to recuperate its investments without risk through a tax benefit scheme provided by a cultural incentive law. New production companies emerged that specialized in putting on shows in the "Broadway format." Artists who previously worked sporadically with musicals - like Claudia Raia, Claudio Botelho, Daniel Salve, and others - began to regularly exercise the function of actors, translators, and directors in these new productions. The desires repressed over the years - expressed not only in the continual attempt to produce shows in dialogue with Broadway repertoires, but also in English school courses - could finally find a home in the promising horizon of work that began to emerge. The result was the creation of expensive shows and the building of new theatre halls, as we saw at the start of the article. The São Paulo theatre scene had changed substantially.

In 200I, asked about the expectations for musicals to continue to be produced in Brazil, Claudia Raia would say: "The future is promising" (Franco, 200I: E5). What sounded like a prophecy gradually became true with the consolidation of a system of shows, schools, and producers. Ten years later, O Estado de São Paulo printed a resounding headline: "A decade to the sound of musicals - ten years after the premiere of the precursor Les misérables, Broadway-style shows have conquered terrain." The triumphant tone, the narrative of success and the confidence of the subjects involved took up half a page of the newspaper. According to the text, "everything began on 25 April 200 I when Les misérables opened at the Teatro Abril [...], beginning a new and productive era" (Brasil, 20I I: D4). The enthusiastic description situated the experience in "a true [theatrical] revolution."

Subjects, investments, legislation, and desires converged to establish 
this theatre system in continual reference to Broadway, a radiating centre interested in exporting aesthetic and political parameters. This particular system of musical theatre production was constituted on an aesthetic and organizational foreign dependency. Over the years, subjects prepared their bodies, improved their production techniques, and invested in new knowledge. In other words, the professionalization of this specific São Paulo scene only became possible by adapting to US models. The insistent accusation that national artists lacked the technical skills to perform musicals is an example of the conventions that served as a parameter for comparison and evaluation.

This type of phenomenon reveals how, more than a mere reference point or imposition, foreign repertoires - in peripheral countries like Brazil - are only realized when appropriated and materialized in "national" bodies, voices, and gestures (Machado, 20I8). Only in this way would it be possible to ensure - via musicals, dramas and acting - the desired insertion of "Brazil" in a symbolic register taken as "international."

Received on 2/Apr/20I9| Revised on I6/Aug/20I9|Approved on I6/Aug/20I9

Bernardo Fonseca Machado has a PhD from the Department of Social Anthropology at USP. He is author of the articles "Sonhos que migram: atrizes e atores brasileiros em Nova York" and "Emoções em disputa: usos do 'amor' em manifestações", and coedited the collection Marcadores sociais das diferenças: fluxos, trânsitos e intersecções. Between 2015 and 2016, he was visiting student research collaborator at Princeton University. He worked as a replacement professor between 2018 and 2019 at the Faculty of Social Sciences of UFG. In 20I9, he began a Postdoctorate at Unicamp with a Fapesp award (process no. 20I9/087I3-2). 


\section{NOTES}

I A first version of this text was presented at the $42 \mathrm{nd}$ annual meeting of ANPOCS. My thanks for the valuable comments from the people present, especially Bernardo Ricupero, Simone Meucci and Heloisa Pontes. The text was transformed into Chapter 2 of my doctoral thesis, Atos da diferença: trânsitos teatrais entre São Paulo e Nova York no início do século XXI, presented at the University of São Paulo (2018) under the supervision of Lilia Schwarcz. This article is based on the thesis version. I thank the generous suggestions of both the anonymous reviewers and the journal's editors. Their comments helped me improve and develop these ideas.

2 All the figures cited in the text were adjusted for the equivalent in US dollars using the tool available on the website of the Brazilian Central Bank: <https://www.bcb.gov.br/ conversao> Accessed 23 December 2020.

3 The information on the producer was obtained from the lengthy interview granted to Tania Carvalho (2008).

4 My fair lady is a musical based on the play Pygmalion by Bernard Shaw, with libretto and lyrics by Alan Jay Lerner and music by Frederick Loewe. The show opened on Broadway on I5 March 1956. Until the end of its run, in 1962, the show was presented 2,7I7 times, a record at the time.

5 To learn more about the trajectory of Brazilian actresses during the period, I suggest consulting Pontes (2010).

6 Created, directed and choreographed by Michael Bennett, the Chorus line's libretto was written by James Kirkwood Jr. and Nicholas Dante. With lyrics by Edward Kleban and music by Marvin Hamlisch, the show opened in April I975, remaining 15 years on Broadway without interruption.

7 According to the "citizen tool" made available by the Central Bank, the amount would correspond in November 2020 to $R \$ 4,051,703.82$. As a parameter, I used the adjustment provided by IPCA/IBGE available on the website of the Brazilian Central Bank: <https://www3.bcb.gov.br/CALCIDA$\mathrm{DAO} /$ publico/exibirFormCorrecaoValores.do? method=exi birFormCorrecaoValores>. Accessed 23 December 2020.

8 Initially, each share was worth Cr\$ I.5 million (around R\$ 20,258 when adjusted for November 2020), but, after ad- 
justments, they remained fixed at $\mathrm{Cr} \$ 3$ million (or approximately $\mathrm{R} \$ 40,517$ in November 2020).

9 The accusation of a lack of technique does not emerge so saliently when we analyse other aesthetics and periods of Brazilian musical theatre (Veneziano, I99I; Steves, 20I5).

Io Created in 1964, AMDA is one of the oldest conservatories for training in performing arts in the United States. Today it has campuses in New York and Los Angeles, and offers programs in Acting, Musical Theatre, Dance and Performing Arts.

II With lyrics, music and plot written by Jonathan Larson, Rent was premiered in I996. In the storyline, a group of friends live in I980s New York, resisting the economic difficulty, the AIDS epidemic, amid widespread drug use.

I2 To learn more about the changes, see Moisés (I998).

I3 A novelist, playwright and filmmaker born in 1946, in Manaus, Souza would enrol in Social Sciences at the university, interrupting his studies in 1969 when persecuted by the military dictatorship. He was the president of the National Art Foundation (Funarte) of MinC between I995 and 2002.

I4 To convert the US dollar to the Brazilian real, I needed to proceed in two stages. First, I used the currency conversion tool on the Central Bank website (https://www.bcb.gov.br/ conversao) respecting the dollar conversion rate at the date of the report. Next, I updated the figure, already in Brazilian reais, for December 2018, according to the National Broad Consumer Price Index (IPCA) of the Brazilian Institute of Geography and Statistics (IBGE). Sites accessed 23 December 2020.

I5 The musical was based on the novel of the Argentinean writer Manuel Puig and told the story of Valentim, a Marxist revolutionary accused of terrorism, and Molina, a homosexual in prison for corrupting minors, forced to occupy a small cell in a prison somewhere in South America.

I6 The Central Bank's currency conversion tool was used, 23 December 2020.

I7 At the time, the amount corresponded to R $\$ 9 I, 890,000$, using the Central Bank's conversion tool. In December 2020, this sum corresponded to $\mathrm{R} \$ 279,944,28 \mathrm{I}$, adjusted using the IPCA/ IBGE parameters, using the Central Bank's "citizen tool." 


\section{BIBLIOGRAPHY}

Almeida Junior, José Simões. (2007). Cartografia política dos lugares teatrais da cidade de São Paulo - I999 a 2004. Tese de Doutorado. PGECA/Universidade de São Paulo.

Arruda, Maria Arminda do Nascimento. (2003). A política cultural: regulação estatal e mecenato privado. Tempo Social, I5/2, p. I77-I93.

Arruda, Maria Arminda do Nascimento. (200I). Metrópole e cultura: São Paulo no meio século XX. Bauru: Edusc.

Bourdieu, Pierre. (2007). A distinção: crítica social do julgamento. São Paulo/Porto Alegre: Edusp/Zouk.

Brasil, Ubiratan. (20I4). O rei leão encerra temporada no Brasil com recorde de público. O Estado de São Paulo. Caderno 2, s.p.

Brasil, Ubiratan. (20I I). Uma década ao som dos musicais. O Estado de São Paulo, Caderno2, p. D4.

Camargo, José Carlos. (I989). Cariocas elegem a "gostosona" Claudia Raia atriz do verão. Folha de S. Paulo, p. E3.

Cardoso, Adriana; Fernandes, Angelo José \& Cardoso Filho, Cassio. (2016). Breve história do teatro musical no Brasil e compilação de seus títulos. Revista Música Hodie, Goiânia, I6, p. 29-44.

Carvalho, Tania. (2009). Charles Möeller e Claudio Botelho: os reis dos musicais. São Paulo: Imprensa Oficial do Estado de São Paulo.

Carvalho, Tania. (2008). A história da publicidade, rádio, televisão e teatro brasileiros na visão de Victor Berbara: o homem das mil faces. São Paulo: Imprensa Oficial do Estado de São Paulo. Castelo, José. (I995). Falabella busca os sentimentos comuns. O Estado de São Paulo. Caderno 2, p. Di.

CavalcantI, Virginia. (1987). Claudia canta. Vestida. O Estado de São Paulo. Caderno 2, p. Di.

Charle, Christophe. (2012). A gênese da sociedade do espetáculo: teatro em Paris, Berlim, Londres e Viena. Present. Heloisa Pontes. Transl. Hildegard Feist. Ed. Sergio Miceli. São Paulo: Cia das Letras.

Costa, Iná Camargo \& Carvalho, Dorberto. (2008). A luta dos grupos teatrais de São Paulo por políticas públicas para a 
cultura: os cinco primeiros anos da lei de fomento ao teatro. São Paulo: Cooperativa Paulista de Teatro.

Costa, José da. (2009). Teatro contemporâneo no Brasil: criações partilhadas e presença diferida. Rio de Janeiro: 7Letras.

Dias, Mauro. (1994). Falabella atualiza mundo das criaturas de Disney. O Estado de São Paulo, p. D2.

Duarte, Márcia de Freitas. (2015). Práticas de organizar na indústria criativa: a produção de um espetáculo de teatro musical em São Paulo, SP. Tese de Doutorado. CDAE/Fundação Getulio Vargas.

Fernades, Silvia. (2010). Teatralidades contemporâneas. São Paulo: Perspectiva/Fapesp.

Franco, Marcella. (200I). Otimismo marca encontro sobre futuro dos musicais - a convite da Folha, cinco intérpretes de peças nacionais debatem gênero. Folha de S. Paulo, Ilustrada, p. E5.

Gama, Júlio. (I999a). O musical dos anos 90 - estreia em São Paulo a bem cuidada produção de Rent, de Jonathan Larson, com I5 atores, cantores e bailarinos supervisionados pelos produtores norte-americanos e sob direção geral de Billy Bond. O Estado de São Paulo, Caderno 2, p. Di7. Gama, Júlio. (I999b). Sonho de ser ator movimenta a estreia de Rent - quase mil pessoas tentam vaga na versão nacional do musical, que estreia em outubro. O Estado de São Paulo. Caderno 2, p. Di.

Gama, Júlio. (I998). Falabella dá adeus ao besteirol com nova peça. O Estado de São Paulo, Caderno 2, p. Di.

Gamerman, Ellen. (2010). Exporting Broadway: the business of sending musicals abroad has never been bigger. The Wall Street Journal. Available in: <https://www.wsj. com/articles/SBIoooI424052748704220704575367I320502 34II8> Access in 24 March, 2019.

Gomes, Tiago de Melo. (2004). Um espelho no palco: identidades sociais e massificação da cultura no teatro de revista dos anos 1920. Campinas: Editora Unicamp.

Gonçalves Dias, Caio. (20I4). Da "Antropologia Filosófica" ao "Do-In Antropológico": um estudo crítico da ideia de políticas culturais no Brasil (1985-2013). Tese de Doutorado. PPGAS/ Universidade Federal do Rio de Janeiro. 
Krüeger, Cauê. (2008). Experiência social e expressão cômica: os Parlapatões, Patifes e Paspalhões. Dissertação de Mestrado. PPGAS/Universidade Estadual de Campinas.

Lopes, Antonio Herculano. (1999) Inventing a mestizo identity: musical theater in Rio de Janeiro I900-I922. Doctoral thesis in Performance Studies. New York University.

Machado, Bernardo Fonseca. (2018). Atos da diferença: trânsitos teatrais entre São Paulo e Nova York no início do século XXI. Tese de Doutorado. PPGAS/Universidade de São Paulo.

Machado, Bernardo Fonseca. (2012). Iluminando a cena: um estudo sobre o cenário teatral nas décadas de 1990 e $2000 \mathrm{em}$ São Paulo. Dissertação de Mestrado. PPGAS/Universidade de São Paulo.

Marques, Fernando. (20I4). Com os séculos nos olhos: teatro musical e político no Brasil dos anos 1960 e i970. São Paulo: Perspectiva.

McMillin, Scott. (2006). The musical as drama. Princeton: Princeton University Press.

Medeiros, Jotabê. (200I). Grupo mexicano domina mercado de show biz. O Estado de São Paulo, Caderno de Economia, p. B30.

Moisés, José Álvaro. (I998). Os efeitos das leis de incentivo. In: Weffort, Francisco \& Souza, Márcio (eds.). Um olhar sobre a cultura brasileira. Rio de Janeiro: Associação de Amigos da Funarte, p. 42I-444.

Nunes, Lucélia. (2000a). O beijo da mulher aranha ganha superprodução. O Estado de São Paulo. Caderno 2, p. D3.

Nunes, Lucélia. (200ob). Mulher aranha arma a sua teia em São Paulo. O Estado de São Paulo. Caderno 2, p. D5.

Oliveira, Regina. (I996). Claudia Raia estreia novo show em Ribeirão - Caia na Raia, que apresenta I6 quadros diferentes, mistura música, dança e teatro e terá quatro apresentações. Folha de S. Paulo. Acontece, p. 5.

Pierce, Leslie. (2013). Teatro musical: um guia prático de stage management. São Paulo: Giostri Editora.

Pimenta, Ângela. (1989). Senhoras e senhores, o Cabaret vem aí - em fase de pré-ensaio, o musical que fez a fama de Liza Minelli e Joel Frey estreia em setembro no Procó- 
pio Ferreira. Para elenco escolhido, a hora é de sangue e suor. O Estado de São Paulo. Caderno 2, p. Di.

Pitta, Rodrigo. (200I). Tudo igual como sempre na Broadway - a região que exibe musicais não apresenta novidades, mas ainda atrai muito público. O Estado de São Paulo, Caderno 2, p. D7.

Pocket Broadway. (I998). O Estado de São Paulo, Caderno 2, p. D2. Available at <https://acervo.estadao.com.br/pagi na/\#!/I998I023-38356-spo-0073-cd2-d27-not/busca/ Pocket+Broadway>.

Pontes, Heloísa. (20I0). Intérpretes da metrópole - história social e relações de gênero no teatro e no campo intelectual (I940-I968). São Paulo: Edusp/Fapesp.

Ridenti, Marcelo. (2010). Brasilidade revolucionária: um século de cultura e política. São Paulo: Editora Unesp.

Rocha, Janaína. (2000). Grupo leva toda a emoção de Cazuza a Tom Brasil. O Estado de São Paulo, Caderno 2, p. D7. Romeo, Simone do Prado. (2016). O movimento Arte contra a barbárie: gênese, estratégias de legitimação e princípios de hierarquização das práticas teatrais em São Paulo (I998-2002). Dissertação de Mestrado. PPGHS/Universidade Federal de São Paulo.

Sá Moreira, Adriana. (20I4). A cultura como mercadoria: o atual modelo de financiamento cultural, definido pelas leis de incentivo, como veículo de produções midiáticas e mercadológicas em São Paulo. Dissertação de Mestrado. PMC/Faculdade Cásper Líbero.

Santos, Valmir. (200I). Miseráveis milionários - Les misérables estreia amanhã em São Paulo. Folha de S. Paulo, Ilustrada, p. EI.

Sarlo, Beatriz. (2010). Modernidade periférica: Buenos Aires I920 e I930. Trad. e posfácio Júlio Pimentel Pinto. Prólogo: Sergio Miceli. São Paulo: Cosac Naify.

Staut Alexandre. (200I). A Broadway é aqui. Folha de $S$. Paulo, Guia da Folha, p. 9-Io.

Steves, Gerson da Silva. (20I5). A Broadway não é aqui: panorama do teatro musical no Brasil. São Paulo: Giostri Editora. Vale, Israel do. (200I). Fenômeno é bancado por empresa mexicana. Folha de S. Paulo, Ilustrada, p. E5. 
Veneziano, Neyde. (I99I). O teatro de revista no Brasil: dramaturgia e convenções. Campinas: Pontes/Editora Unicamp. WasilewskI, Luis Francisco. (2008). Isto é besteirol: a obra dramatúrgica de Vicente Pereira no âmbito do Teatro Besteirol. Dissertação de Mestrado. FFLCH/Universidade de São Paulo.

Weffort, Francisco \& Souza, Márcio (eds.). (I998). Um olhar sobre a cultura brasileira. Rio de Janeiro: Associação de Amigos da Funarte.

Weiss, Ana. (I999). Artistas promovem debate sobre arte e política. O Estado de São Paulo, Caderno 2, p. D3. 


\section{EXPERIÊNCIA SOCIAL E TEATRO MUSICAL ESTADUNIDENSE NOS PALCOS PAULISTANOS}

Resumo

Na virada para o século XXI, espetáculos da Broadway passaram a ser largamente produzidos em diversos países. No Brasil, particularmente na cidade de São Paulo, as condições legislativas, os interesses empresariais e o fascínio de parcela da classe artística se combinaram e permitiram a criação de um sistema de montagens na cidade. Este texto esquadrinha os fatores sociais que considero essenciais para a abundante produção de musicais nos últimos anos. Estou particularmente interessado em descrever como determinados agentes orquestraram múltiplos procedimentos e interesses na ordernação de um cenário ímpar e profícuo que alterou a produção cênica da cidade. Minha aposta reside na compreensão do teatro como uma forma expressiva, um termômetro de desejos e práticas sociais.

\section{SOCIAL EXPERIENCE AND US MUSICAL THEATRE ON SÃO PAULO'S STAGES}

\footnotetext{
Abstract

At the turn of the twenty-first century, Broadway musicals began to be produced in many countries outside the United States. In Brazil, particularly the city of São Paulo, new laws, business interests, and the fascination of some artists with US productions converged to enable the creation of a new system of musicals. In this article I examine the social elements I consider fundamental to understanding the proliferation of musicals in recent years. My description focuses especially on how some actors orchestrated multiple procedures and interests to organize a unique and fertile setting that changed the city's theatrical production. In the process, I explore theatre as an expressive form that acts as a thermometer of social desires and practices.
}

Palavras-chave

Experiência social; teatro musical;

São Paulo;

Broadway.

Keywords

Social experience;

musical theatre;

São Paulo;

Broadway. 